\title{
Identification of Plant Morphology of Taro as a Potential Source of Carbohydrates
}

\author{
Zulfadly Syarif ${ }^{\# 1}$, Nasrez Akhir ${ }^{\# 2}$, and Benni Satria ${ }^{\# 3}$ \\ ${ }^{\#}$ Department of Agroecotecnology, Faculty of Agriculture, Andalas University, Padang 25163, Indonesia \\ Email: ${ }^{1}$ syarif_zulfadly@yahoo.com, ${ }^{2}$ nasrezaakhir@gmail.com, ${ }^{3}$ benni_bd@yahoo.com
}

\begin{abstract}
Taro plants have long been cultivated and utilized as a source of additional food in Indonesia. Besides being a source of food, taro can also be used for industrial purposes, such as cosmetic and plastic raw materials. Taro tuber characteristics determine its use. Research in the form of a survey conducted in 2016, by observing and studying the morphological characteristics of Taro, in three Districts in West Sumatra Province. The research objective is to obtain information on Taro plants that have the potential to be made as carbohydrates in supporting food security and diversification as well as providing with initial information on Taro germplasm. To see the level of plant relatedness, NTSYS program version 2.1 was applied. Results of the study managed to collect 47 accessions, with differences in diversity between locations, and of that number, based on morphological characters of tubers observed, there were 32 accessions that have the potential to serve as a source of carbohydrate. Research is still ongoing to test the properties of carbohydrates and analysis of genetic variability.
\end{abstract}

Keywords—characteristics; germplasm; tuber; West Sumatra

\section{INTRODUCTION}

Result of study conducted by Environment Ministry Republic Indonesia as as cited by the Center for Food Availability and Vulnerability, Food Security Agency, Ministry of Agriculture Republic Indonesia in 2012 that Indonesia has at least 100 species of plant seeds, tubers, sago, flour and sugar producer as a source of carbohydrate. However, only a few food sources of carbohydrates are known widely and intensively used for consumption, such as rice, maize, cassava, sweet potato, sago and others. Even some of the food has been replaced by rice and wheat. The potential of local food sources of carbohydrates in Indonesia has many and various kinds such as maize, cassava, sweet potato, sago, adung, taro, bananas, breadfruit, taro and others. Food can be developed in an effort to accelerate the diversification [1].

The diversity of food crops in Indonesia can be developed to overcome the food problem. Types of tubers that can be utilized more optimally as a staple food rice substitutes include cassava, sweet potato, taro, purse, arrowroot, and canna. These tubers have a lot of the preeminent, among them having a high content of carbohydrates as energy sources [2].

Tubers that can be used optimally as a substitute for rice include cassava, sweet potato, taro, bags, arrowroot, and canna. Tubers have many advantages including a high content of carbohydrates as an energy source and have a strategic role as non-rice food reserves in the future [3].

Some areas in Indonesia has the potential of traditional staple food of their own; such as tubers, sago in some areas of Papua, maize and cassava in the islands of Maluku, taro in the Mentawai Islands of West Sumatra province and in Biak, Papua, in line with it [4] in its report also mentioned that based on the fact that in some the area is sometimes easier to grow crops tersebet than rice, so it has a great opportunity to optimize the development of traditional staple food to support the achievement of food diversification in Indonesia, and [5] reported that in few places, such as Irian Jaya or Papua, Mentawai Islands (West Sumatera), Sangihe Talaud (North Sulawesi) and at least in one place in East Jawa (Cemoro Sewu), however, local people still consume taro asides from other staple foods.

Comparatively of their ash content (4.38\%) compared with wheat flour $(1.82 \%)$, it can be concluded that taro flour contains adequate amounts of minerals, so available of carbohydrates in wheat flour falls in level $68.75 \%$, within the range of that of taro i.e., 79.70\%. According to [6] on his research shows that comparatively, comparable values were also observed in the level of crude fiber wheat which is $1.7 \%$ and for taro at the level of $1.87 \%$ of the flour, the flour seen from the fat content is generally low $(0.98 \%)$, but this value is far higher than the taro flour.

Taro has a large genetic variation giving more opportunity to obtain superior taro plants for plant breeding purposes. 
Plant breeding is an applied science that utilizes knowledge of genetics, pathology, plant physiology, statistics, and molecular biology for use in the modification of plant species for the purposes or human needs. The ultimate objective of breeding plants is plants that having high economic value [7]-[9].

The positive and significant correlation between the number of suckers/stand and a number of leaves/stand of taro indicated that closely related genes controlled the two parameters. Therefore, an increase in the number of suckers also increases the number of the leaves/stand which also increases yield. The positive and significant correlation between the number of suckers and number of cormels also showed that they are controlled by similar genes[10].

Based on the above-mentioned information, and in accordance with reference [11], the morphological diversity is influenced by the environment. Identification can be made in three ways: 1) identification based on morphology, 2) identification based on cytology, 3) identification based on DNA banding pattern (molecular) [12]. Research reported here was aimed at identifying the taro plant morphology, as a potential source of carbohydrates other than rice which until now is still the main source of carbohydrates (staple food) in Indonesia.

\section{MATERIAL AND METHODS}

This research is an ongoing series and the first part of the research plan of the Council of Professors of the University of Andalas, 2016-2018. The first study lasted for 5 months which is divided into two stages, the first study carried out in the form of surveys carried out during the three months from April to June 2016. The location study performed entirely in the province of West Sumatra. Exploration is done by conducting a survey using descriptive and purposive sampling method. Identification and characterization of taro plant morphology done by field observation method that includes observation of plants and tubers of taro that includes observation with the observation criteria: derived from mother plants which have been rooted and samples were taken $10 \%$ of the population. morphological observation include: color bars, long petiole $(\mathrm{cm})$, leaf length $(\mathrm{cm})$, leaf width $(\mathrm{cm})$, leaf shape, flower color, flower number per group, amount of interest that most of the group or stalk, form bulb, tuber color, tuber weight (g), bulb diameter (cm). Observation of the morphological characteristics of taro plants was conducted over 2 months ie from June to July 2016. The research covers three regencies in West Sumatra province, Indonesia, namely: Kepulauan Mentawai, Padang Pariaman, and LimaPuluhKota and agronomic laboratory Andalas University, Padang, Province West Sumatra, Indonesia.

Morphological observation includes the color of the stem, petiole length $(\mathrm{cm})$, leaf length $(\mathrm{cm})$, leaf width $(\mathrm{cm})$, leaf shape, tuber shape, bulb color, tuber weight $(\mathrm{g})$, tuber diameter $(\mathrm{cm})$. To determine the similarity of accessions the program Numerical Taxonomy and Multivariate Analysis System (NTSYS) [13] was used.

\section{RESULTS AND DISCUSSION}

\section{A. Profile Research Locations}

The research was conducted in three districts in the Province of West Sumatra: District Lima Puluh Kota, Padang Pariaman and the Mentawai Islands, District Lima Puluh Kota is one of the regencies in West Sumatra Province who had detectable Taro plants grow sporadically in some Districts and Kenagarian. Lima Puluh Kota district has an area of $3354.30 \mathrm{~km}^{2}$, which means $7.94 \%$ of the mainland's West Sumatra Province which covers 42,229.64 km². Lima Puluh Kota district consists of 13 sub-districts and 79 villages.

Based on the geographical location, Lima Puluh Kota District lies between 2528,7 LU $0^{\circ}$ and $0^{\circ} 2214,52 \mathrm{LS}$ and at $100^{\circ} 1544,10-100^{\circ} 5047,80 \mathrm{BT}$. Altitude 110-2261 m above sea level. District Lima Puluh Kota has a topography dominated by flat, undulating and hilly areas. Lima Puluh Kota District has the tropical climate with temperatures between $20-25^{\circ} \mathrm{C}$, with average rainfall ranging from 2200 $3750 \mathrm{~mm} /$ year.

Padang Pariaman district is located in the most western part of Sumatra island, consisting of sub-districts of Batang Anai, Sungai Geringging, Sungai Limau, V Koto Kampung Dalam, V Koto Timur and Sungai Sariak. Altitude 0-250 m above sea level. Padang Pariaman has a flat topography, undulating and hilly. Its area is tropical with temperatures between $27-30^{\circ} \mathrm{C}$, with an average rainfall of $3000 \mathrm{~mm} /$ year.

The Mentawai Islands, located in the province of West Sumatra and is surrounded by the Indian Ocean, made up of 10 districts, 43 villages and 202 hamlets. Observations on taro conducted one of which is the sub-district of South Siberut which has an area of $508.33 \mathrm{~km} 2(8.46 \%)$ with the capital district is Maileppet, while the sub-district of North Siberut has an area of $816.11 \mathrm{~km} 2(13.58 \%)$ with the capital Sikabaluan Muara district.

The identification and characterization of taro plants have been conducted in three districts i.e. Lima Puluh Kota, Mentawai Island, and Padang Pariaman. There were few morphological variations among 32 types of local varieties on the two taro cultivars (Xanthosoma, and Colocasia) under study. All cultivars of Xanthosoma did not produce stolons, whereas few of local varieties among the Colocasia cultivars produce stolons there were Talas Merah, Bio Laiket, Ngalitet, Sibahaugna, Sususuro, dan Kan Simugmug. In addition, besides that, there are few variations in the characteristics of taro, where there were 11 assesi of taro which has suckers are as follows: Bio Laiket, Sikalagatna, Kalagaita, Silakkuk, Sibahaugna, Sikobou, Sipungatna, Bawang, Birai, Bio, Kan Putih, and Talas Putih.

Growing types of taro plants were observed for a range of plants that is the distance measured between the outer leaf to leaf facing each other. The widest at $300 \mathrm{~cm}$ is the type of taro Sebawan. This distance is the maximum horizontal distance reached by leaves quite wide for more than $100 \mathrm{~cm}$. Of all genotypes, the shortest is $80 \mathrm{~cm}$ which is the type of coconut taro, according to [14] the tillering and plant size showed high CV (coefficient of variation) values indicating that there was more variation for these phenotypic characters. Taro is highly pan-tropical in its distribution and cultivation, and it is probably the variability in these 
important phenotypic characters that has helped the crop survive and adapt to different agro-ecological conditions.

According to [15], the size and shape of the taro plant morphology vary which can be influenced by environmental and genetic factors. A morphological description on each of the taro plants found in three research sites is shown in Table 1 .

Based on the frequency of the phenotypic characters across the 32 accessions, the observations made based on morphological characteristics include stems and leaves obtained that cultivars Colocasia sp and Xhantosoma sp, has narrow diversity. The narrow diversity caused by vegetative propagation taro plants is stolon or tiller tuber taro, as shown in Fig. 1 (a-b).

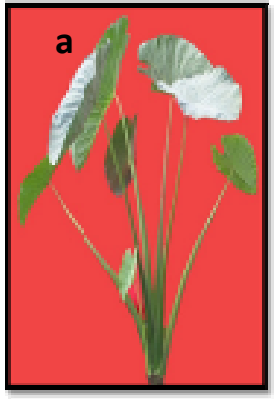

Colocasia sp

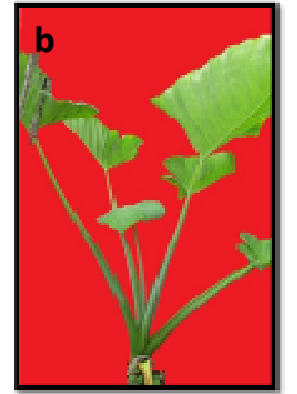

Xhantosoma $s p$
Fig. 1 (a-b) Two types cultivars of taro: Colocasia sp and Xhantosoma sp

TABLE I

The Observation of Plant Morphological Characters of Taro in District of Lima Puluh Kota (LPK), MEnTAWAi IsLANDS (KM), and Padang PARIAMAN (PP)

\begin{tabular}{|c|c|c|c|c|c|c|}
\hline \multirow{2}{*}{ No. Acc } & \multirow{2}{*}{ Local Name } & \multirow{2}{*}{ Cultivar of Taro } & \multicolumn{4}{|c|}{ Characteristics } \\
\hline & & & $\begin{array}{l}\text { Plant height } \\
\text { (cm) }\end{array}$ & $\begin{array}{c}\text { Number of } \\
\text { stolon }\end{array}$ & $\begin{array}{c}\text { Length of stolon } \\
(\mathrm{cm})\end{array}$ & $\begin{array}{l}\text { Number of } \\
\text { sucker }\end{array}$ \\
\hline $1 \mathrm{PP}$ & Talas hitam & Xanthosoma & 115 & non & - & non \\
\hline $2 \mathrm{PP}$ & Talas banyak anak & Colocasia & 97 & non & - & non \\
\hline $3 \mathrm{PP}$ & Talas Kuti & Xanthosoma & 110 & non & - & non \\
\hline $4 \mathrm{PP}$ & Talas Merah & Colocasia & 98 & 1 & 18 & non \\
\hline $5 \mathrm{PP}$ & Talas Kuamyan & Colocasia & 105 & non & - & non \\
\hline $6 \mathrm{PP}$ & Talas Ungu & Xanthosoma & 112 & non & - & non \\
\hline $7 \mathrm{KM}$ & Bio Laiket & Colocasia & 75 & 1 & 15 & 1 \\
\hline $8 \mathrm{KM}$ & Sikalagatna & Colocasia & 91 & non & - & 8 \\
\hline $9 \mathrm{KM}$ & Kalagaita & Colocasia & 110 & non & - & 11 \\
\hline $10 \mathrm{KM}$ & Silakkuk & Colocasia & 96 & non & - & 19 \\
\hline $11 \mathrm{KM}$ & Simasurat Emu & Colocasia & 104 & non & - & non \\
\hline $12 \mathrm{KM}$ & Ngalitet & Colocasia & 125 & 1 & 21 & \\
\hline $13 \mathrm{KM}$ & Pulelegleg Simaingo & Colocasia & 73 & non & - & non \\
\hline $14 \mathrm{KM}$ & Sibahaugna & Colocasia & 85 & 1 & 10 & 1 \\
\hline $15 \mathrm{KM}$ & Sikobou & Colocasia & 89 & non & - & 5 \\
\hline $16 \mathrm{KM}$ & Sipungatna & Colocasia & 125 & non & - & 2 \\
\hline $17 \mathrm{KM}$ & Sasarewu & Colocasia & 93 & non & - & non \\
\hline $18 \mathrm{KM}$ & Sususuro & Colocasia & 135 & 4 & & non \\
\hline $19 \mathrm{KM}$ & Bawang & Colocasia & 85 & non & - & 12 \\
\hline $20 \mathrm{KM}$ & Birai & Colocasia & 183 & non & - & 7 \\
\hline $21 \mathrm{KM}$ & Bio & Xanthosoma & 275 & non & - & 3 \\
\hline $22 \mathrm{KM}$ & Kan Putih & Colocasia & 126 & non & - & 4 \\
\hline $23 \mathrm{KM}$ & Kan Padegan & Colocasia & 92 & non & - & non \\
\hline $24 \mathrm{KM}$ & Maile legleg & Colocasia & 151 & non & - & non \\
\hline $25 \mathrm{KM}$ & Kan Kalegan & Colocasia & 171 & non & - & non \\
\hline $26 \mathrm{KM}$ & Kan Sinangkek & Colocasia & 102 & non & - & non \\
\hline $27 \mathrm{KM}$ & Kan Simugmug & Colocasia & 135 & 1 & 60 & non \\
\hline $28 \mathrm{LPK}$ & Talas Hitam & Xanthosoma & 112 & non & - & non \\
\hline 29 LPK & Talas Sebawan & Colocasia & 110 & non & - & 5 \\
\hline $30 \mathrm{LPK}$ & Talas Putih & Xanthosoma & 160 & non & - & non \\
\hline $31 \mathrm{LPK}$ & Talas Kelapa & Colocasia & 118 & non & - & non \\
\hline $32 \mathrm{LPK}$ & Talas Cina & Colocasia & 121 & non & - & non \\
\hline
\end{tabular}

Plant height of all samples measured by the vertical distance in reaching the leaves measured from the ground. Talas highest on the type of taro Sebawan, $275 \mathrm{~cm}$, and 120 $\mathrm{cm}$ lowest on the type of taro Kelapa. Stolon of the plant is not found to exist only shoot directly attached (sucker) contained in the type of taro Sebawan.
Further observation of the morphological characteristics of the underground parts of the plant include taro tuber; it has been specified that underground parts, such as roots and tubers, are of some taxonomic value in plants [16], were recorded for 32 accessions of taro which has potential as a source of carbohydrates. 
Taro tuber has two forms: Qorum bulbs and antiqorum. Weight each cormus also vary. Talas Hitam has a length of $40 \mathrm{~cm}$ with a weight of $1.7 \mathrm{~kg}$ and has a branched bulb called cormel with a total weight of $1.4 \mathrm{~kg}$ per clump, with a total number of cormel of 7 pieces. Talas Sebawan taro plants have cormel up to $25 \mathrm{~cm}$ long with a weight of $2.6 \mathrm{~kg}$ but do not have cormel (branch cormus). Same with Talas Hitam, Talas Putih has cormus cormel with a length of 32 $\mathrm{cm}$ belonging cormus length category with a weight of 1.3 $\mathrm{kg}$ and also has a branch (cormel) of 7 pieces with a weight of $1.6 \mathrm{~kg}$, as shown in Fig. 2 (a-b).
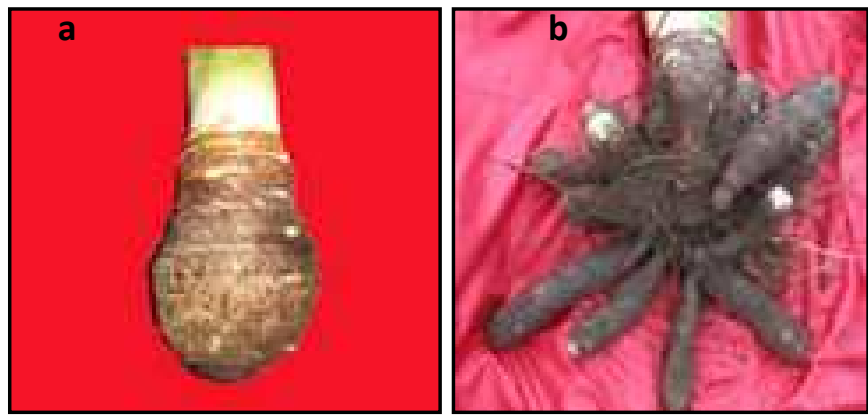

Fig. 2 (a-b) Type Qorum bulbs (Colocosia sp), and antiqorum bulbs ((Xanthosoma sp)

TABLE II

Obervation for Bulbs Character of TARo, in District Lima Puluh Kota (LPK), Mentawai Island ANd Padang PaRiaman (PP)

\begin{tabular}{|c|c|c|c|c|c|c|}
\hline \multirow{2}{*}{$\begin{array}{l}\text { No. } \\
\text { Acc }\end{array}$} & \multirow[t]{2}{*}{ Local Name } & \multicolumn{5}{|c|}{ Characters } \\
\hline & & $\begin{array}{l}\text { Form of } \\
\text { Cormus } \\
\end{array}$ & $\begin{array}{c}\text { Weight of } \\
\text { Cormus (gr) } \\
\end{array}$ & $\begin{array}{c}\begin{array}{c}\text { Leugth of Cormus } \\
(\mathrm{cm})\end{array} \\
\end{array}$ & $\begin{array}{l}\text { Diameter of } \\
\text { Cormus }(\mathrm{cm}) \\
\end{array}$ & Colour of cormus \\
\hline $1 \mathrm{PP}$ & Talas hitam & lengthwise & 1700 & 28 & 7 & redness \\
\hline $2 \mathrm{PP}$ & Talas Banyak anak & ellip & 2600 & 28 & 7 & yellowish \\
\hline $3 \mathrm{PP}$ & Talas Kuti & lengthwise & 1300 & 22 & 9 & yellowish \\
\hline $4 \mathrm{PP}$ & Talas Merah & ellip & 600 & 11 & 5 & yellowish \\
\hline $5 \mathrm{PP}$ & Talas Kumayan & ellip & 1400 & 27 & 8 & yellowish \\
\hline $6 \mathrm{PP}$ & Talas Ungu & lengthwise & 1800 & 32 & 19 & yellowish \\
\hline $7 \mathrm{KM}$ & Bio Laiket & Halter & 490 & 18 & 7 & white \\
\hline $8 \mathrm{KM}$ & Sikalagatna & ellip & 590 & 23 & 7.6 & yellowish \\
\hline $9 \mathrm{KM}$ & \begin{tabular}{|l|} 
Kalagaita \\
\end{tabular} & Ellip & 190 & 12 & 4.9 & yellowish \\
\hline $10 \mathrm{KM}$ & \begin{tabular}{|l} 
Silakkuk \\
\end{tabular} & Unanimous & 150 & 9 & 6.7 & white \\
\hline $11 \mathrm{KM}$ & Simasurat Emu & Ellip & 750 & 21 & 8.5 & white \\
\hline $12 \mathrm{KM}$ & Ngalitet & Ellip & 1009 & 22 & 11 & white \\
\hline $13 \mathrm{KM}$ & Pulelegleg Simaingo & Ellip & 900 & 23 & 9.5 & white \\
\hline $14 \mathrm{KM}$ & \begin{tabular}{|l} 
Sibahaugna \\
\end{tabular} & Ellip & 1800 & 25 & 11.5 & white \\
\hline $15 \mathrm{KM}$ & \begin{tabular}{|l|} 
Sikobou \\
\end{tabular} & Ellip & 580 & 24 & 8 & yellowish \\
\hline $16 \mathrm{KM}$ & Sipungatna & Ellip & 750 & 23 & 7.7 & white \\
\hline $17 \mathrm{KM}$ & Sasarewu & Ellip & 590 & 19 & 7.2 & white \\
\hline $18 \mathrm{KM}$ & \begin{tabular}{|l|} 
Sususuro \\
\end{tabular} & Ellip & 1170 & 24 & 10 & redness \\
\hline $19 \mathrm{KM}$ & \begin{tabular}{|l|} 
Bawang \\
\end{tabular} & cluster & 420 & 14 & 6.5 & white \\
\hline $20 \mathrm{KM}$ & Birai & lengthwise & - & - & - & - \\
\hline $21 \mathrm{KM}$ & Bio & lengthwise & - & - & - & - \\
\hline $22 \mathrm{KM}$ & Kan Putih & Ellip & 540 & 17 & 8.5 & white \\
\hline $23 \mathrm{KM}$ & Kan Padegan & Ellip & 600 & 18.5 & 8 & yellowish \\
\hline $24 \mathrm{KM}$ & Maile legleg & Ellip & 850 & 22 & 7.8 & white \\
\hline $25 \mathrm{KM}$ & Kan Kalegan & Ellip & 1900 & 25 & 7.6 & white \\
\hline $26 \mathrm{KM}$ & Kan Sinangkek & Ellip & 770 & 17.5 & 9.5 & white \\
\hline $27 \mathrm{KM}$ & Kan Simugmug & Ellip & 700 & 27 & 6.4 & \\
\hline $28 \mathrm{LPK}$ & \begin{tabular}{|l|} 
Talas Hitam \\
\end{tabular} & lengthwise & 1.7 & 28 & 7 & white \\
\hline $29 \mathrm{LPK}$ & Talas Sebawan & ellip & 2.6 & 29 & 12 & white \\
\hline $30 \mathrm{LPK}$ & Talas Putih & lengthwise & 1.3 & 15 & 6 & white \\
\hline $31 \mathrm{LPK}$ & \begin{tabular}{|l|} 
Talas Kelapa \\
\end{tabular} & lengthwise & 0.8 & 18 & 9 & yellowish \\
\hline $32 \mathrm{LPK}$ & Talas Cina & ellip & 1.8 & 15 & 8 & White \\
\hline
\end{tabular}

The results of the characterization of taro plants performed on three different plains in the district Lima Puluh Kota, Mentawai Island, and Padang Pariaman obtained the diversity seen in the character of the bulb (cormus). The characterization results show that there is a difference among 32 variants of local varieties of taro. The result of a observation on the characteristic of bulbs of taro in District 
Lima Puluh Kota, Mentawai Island, and Padang Pariaman were shown in Table 2.

\section{B. Analysis of Similarities}

Morphological similarity between samples can be tested using cluster analysis (average group analysis), which results in the form dendrogram or tree diagram. The resemblance relationship patterns observed taro plants do a combined analysis of morphological characters based on the similarity of the 32 accessions of taro plants in three districts (districts of Lima Puluh Kota, Mentawai Island, and Padang Pariaman). Plant relatedness was determined using NTSYS$\mathrm{PC}$ and shown in Fig. 3

The results of the analysis of 32 accessions have a common matrix on a scale ranging from $32 \%$ to $97 \%(67 \%$ variation) demonstrating three main groups of taro plants when viewed on a $32 \%$ similarity value. The first group was formed by accessions LPKGB (Lima Puluh Kota, Guguk), LPKABRA (Lima Puluh Kota), LPKABT (Lima Puluh Kota), LPKSIPU (Lima Puluh Kota) and LPKSITU (Lima Puluh Kota), the second group was formed by accessions
PPSGTH (Padang Pariaman Sungai Geringging), PPVKDTU (Padang Pariaman V Koto Dalam)), PPSLTP (Padang Pariaman Sungai Limau), PPBATBA (Padang Pariaman Batang Anai), PPSTK (Padang Pariaman Sungai Sariak) and PPVKTM (Padang Pariaman V Koto Timur) and a third group was formed by accessions MSSSika (Mentawai Sikalagatna), MSSila (Mentawai Silakkuk), MSSipu (Mentawai Sipungatna), MSSBio (Mentawai Bio Laiket), MSUKP (Mentawai), MSUKansi (Mentawai Kan Sinangkek), MSSKala (Mentawai Kalagaita), MSSaiko (Mentawai), MSSbi (Mentawai), MSUKankal (Mentawai), MSSBL (Mentawai), MSSngal (Mentawai Ngalitet), MSUKanaimu (Mentawai), MSSima (Mentawai Simasurat EMU), MSUMle (Mentawai), MSSb (Mentawai), MSUKanpa (Mentawai), Msibag (Mentawai), MSSpule (Mentawai), MSSaaisa (Mentawai), MSSusus (Mentawai), furthermore, when viewed in the percentage of similarity of $97 \%$ there is only one group formed by accession MSSaiko and MSSbi.

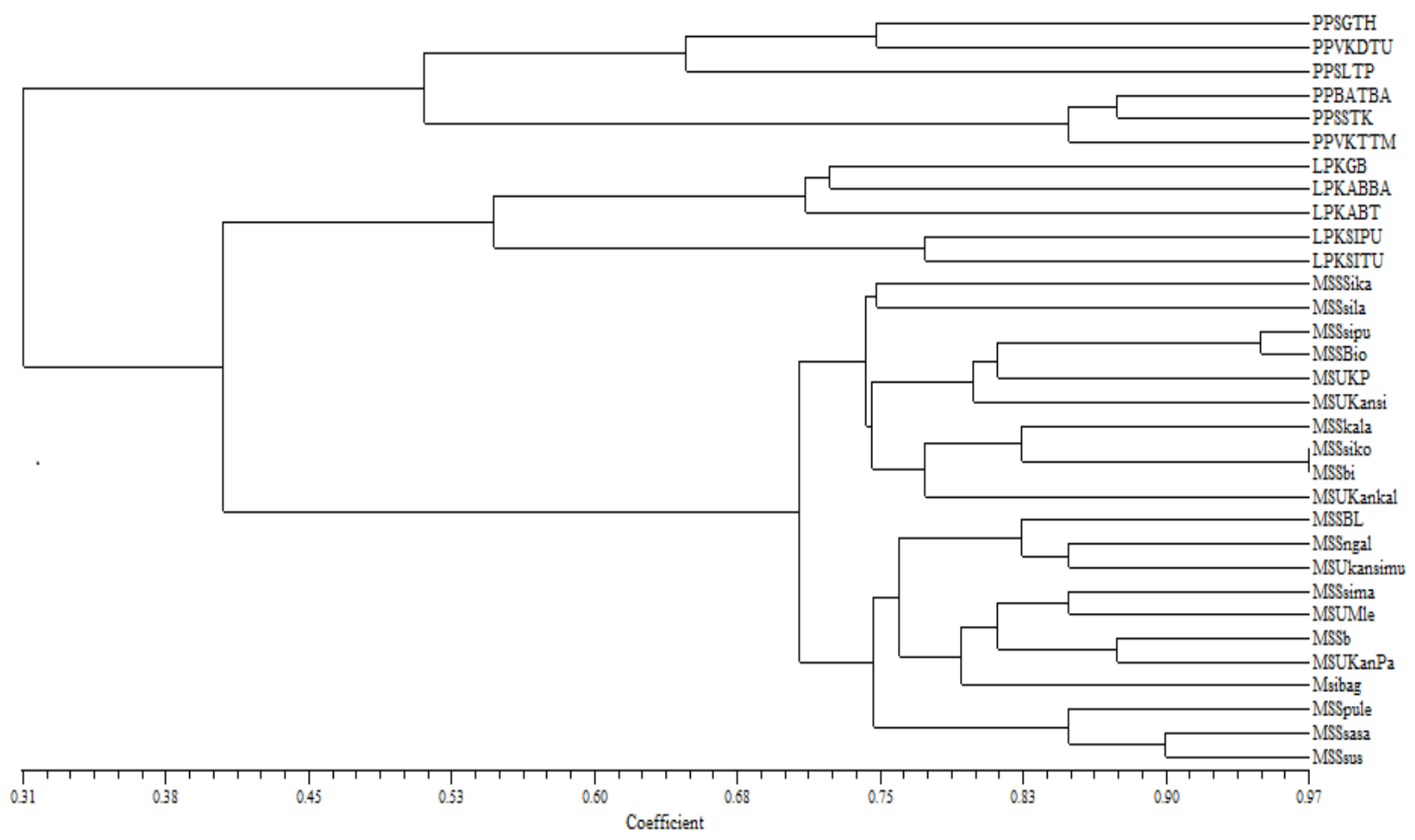

Fig. 3 Dendrogram illustrating the variability and similarity Phenetic Relationship among 32 Cultivar of Taro (Colocasia sp and Xhantosoma sp) from three districts (Lima Puluh Kota, Mentawai Island, and Padang Pariaman)

Analysis of the carbohydrate content of taro tubers which derived by 32 accessions of taro from three districts: Limapuluh Kota, Mentawai Island, and Padang Pariaman. Analysis method to determine the carbohydrate content of 32 local varieties of taro doing by using the calculation Carbohydrate by Difference [17]. From this method, also known the other substances which are protein, fat, water and ash. These calculations were performed by calculating the difference of $100 \%$ minus the percentage of protein, fat, water and ash. The result obtained was the percentage of carbohydrates in tuber which analyzed.

From the analysis of carbohydrate content by using Carbohydrates with a Difference method to 32 accessions of taro local (type cultivars Colocasia sp and Xhantosoma $\mathrm{sp}$ ) in three districts showed that the composition and content of flour all of the taro local consist of carbohydrates and protein in high enough quantities, and of the whole obtained 12 accessions of taro with the highest carbohydrate content as a potential source of carbohydrate as follows: Sibahaugna (78.8765), Pulelegleg Simaingo (77.9654), Talas Banyak Anak (77.7650), Talas Putih (77.5800), Talas Hitam (76.9450), Sususuro (76.8650), Talas China (76.6550), Ngalitet (76.3633), Talas Ungu (75.5438), Talas hitam (75.6870), the results of analysis of 12 accessions of taro flour as shown in Table 3. 
TABLE III

TARo Flour ANALysis on Three District in WeSt Sumatera Province

\begin{tabular}{|c|l|c|c|c|c|c|}
\hline No. & \multicolumn{1}{|c|}{ Local Name } & $\begin{array}{c}\text { Protein content } \\
(\boldsymbol{\%})\end{array}$ & Fat Level & Ash Content & $\begin{array}{c}\text { Carbohydrate } \\
\text { Content }\end{array}$ & $\begin{array}{c}\text { Moisture Content } \\
(\boldsymbol{\%})\end{array}$ \\
\hline 1 & Talas Hitam & 10.6937 & 1.8360 & 2.9230 & 76.9450 & 7.6023 \\
\hline 2 & Talas Sebawan & 11.4632 & 1.8795 & 2.2268 & 75.4590 & 8.9715 \\
\hline 3 & Talas Putih & 9.8745 & 1.9550 & 2.8865 & 77.5800 & 7.7040 \\
\hline 4 & Talas Cina & 11.2341 & 1.8558 & 2.5580 & 76.6550 & 7.6971 \\
\hline 5 & Talas Hitam & 12.5125 & 3.4380 & 2.7930 & 75.6870 & 5.5695 \\
\hline 6 & Talas Banyak Anak & 11.4521 & 2.8550 & 2.0550 & 77.7650 & 5.8729 \\
\hline 7 & Talas Kumayan & 11.2054 & 2.1250 & 2.1150 & 77.2565 & 7.2981 \\
\hline 8 & Talas Ungu & 11.6550 & 2.5405 & 2.4550 & 75.5438 & 7.8057 \\
\hline 9 & Ngalitet & 11.9250 & 1.9370 & 2.3820 & 76.3633 & 7.3927 \\
\hline 10 & Pulelegleg Simaingo & 9.9550 & 1.8550 & 2.9850 & 77.9654 & 7.2396 \\
\hline 11 & Sibahaugna & 10.3200 & 1.9558 & 2.7580 & 78.8765 & 6.0897 \\
\hline 12 & Sususuro & 10.5432 & 2.2550 & 2.6325 & 76.8650 & 7.7043 \\
\hline
\end{tabular}

Dendrogram generated (Fig. 3) showed that the 32 accessions were broadly grouped into two clusters (26 of cultivars of Colocasia sp, and 6 of cultivars Xanthosoma sp), which were further subdivided into two and five sub-clusters each, respectively (clusters $1 \mathrm{a}$ and $1 \mathrm{~b}$; clusters $2 \mathrm{a}, 2 \mathrm{~b}, 2 \mathrm{c}, 2 \mathrm{~d}$ and $2 \mathrm{e}$ ).

Similarity analysis was used to determine how close and distant resemblance relationship between the genotype of a plant by using morphological characteristics of a plant. The morphological trait can be used for the introduction and describe the similarities in kind. The species has a close resemblance has many similarities from one species to another [18], [19].

The level of similarity and dissimilarity difference is caused by a shopping passage and morphological characters between acceding to a particular group; the difference was both qualitatively and quantitatively. Qualitative characters contribute to these differences such as leaf shape, leaf edge, the color of the leaf blade, the edge color of the leaf blade, the main color of bone-leaf, and petiole color on color ring below the petiole and so on. The quantitative characters used were, plant height, shoot number, leaf length, leaf width, cormus length, cormus weight and a total weight of the cormus.

The difference between the morphological characters of taro plants is also influenced by genetic and environmental factors. Plants need optimal environmental conditions to fully express their genetic potential. This is in line with [20] on their previous research accomplishments also showed that the number of suckers/stand showed a positive and significant correlation with a number of leaves/stand across the measuring intervals. In accordance with [10], the observations that have been conducted also showed a significant positive correlation between the amount of suction and / stand and a number of leaves / stand taro indicating that this gene is also linked closely controlled two factors: environmental and genetic.
The correlation between the number of suckers and number of cormels Also Showed that they are controlled by genes which may also be caused by other environmental factors, in lie with [21] found that that gamma ray irradiation could result in random changes in every given dose and the higher the dose is given, the higher the genetic change (diversity) happened to the Bogor taro apical bud culture sample. According to the dendrogram on this research, it is seen that induction of somaclonal variation of Bogor taro with gamma ray irradiation yields diversity up to $51 \%$ in comparison to the parents.

\section{IV.CONCLUSIONS}

Based on identification and characterization the following conclusions can be drawn: Thirty-two accessions of taro plant accessions that originated from three districts (5 accessions of Lima Piluh Kota district, and 21 accessions of Mentawai Island district and 6 accessions of Padang Pariaman district).

Two types of taro plants found were Xanthosoma sp and Colocasia sp. Thirty-two accessions of Taro were broadly grouped into two clusters (26 of cultivars of Colocasia sp, and 6 of cultivars Xanthosoma sp). Three types of cormus were found i.e., cylindric, ellipse, and elongated. Cormus color of taro observed quite varied, ranging from white, yellowish to reddish. The main type cultivated by farmers, was Talas Putih because it has a high potential value if processed into chips and leaves are harvested as a vegetable. From the analysis of 32 accessions, there are three main groups, and similarity matrix values ranged from $32 \%$ to $97 \%$ with a variation of $65 \%$. The highest content of carbohydrates obtained in Taro with Sibahaugna local name, with a value of 78.8765 


\section{ACKNOWLEDGEMENT}

We would like to thank the Laboratory of Agronomy, Faculty of Agriculture, University of Andalas, and Central Laboratory, University of Andalas, colleagues and partners from local governments, especially for a district, Lima Puluh Kota, Mentawai Island, and Padang Pariaman for their help and support to this research.

\section{REFERENCE}

[1] Ariani., M., et al., "Study of Development Strategy of Local Food diversification, the Activity Report of the Social Center for Economic and Policy, Agency for Agricultural Research and Development, Ministry of Agriculture of the Republic of Indonesia, 2013

[2] Liu Q, Donner E, Yin Y, Huang RL and Fan MZ.. "The physicochemical properties and in vitro digestibility of selected cereals, tubers, and legumes grown in China", Food Chem 99: 470477, 2006.

[3] Widodo S., Alfonso, J. B., S. M. and Sarasutha, "Collection and Evaluation of Cassava Cultivation - edible Rare Potential," in Plant Breeding Symposium on Breeding Science IV.Perhimpunan Indonesia, East Java Regional Commissariat, pp. 124-129, 1996.

[4] Widyanti., A., Indryati S. and Asteria D.K., "Reducing The Dependency on Rice as Staple Food in Indonesia - A Behaviour Intervention Approach, J. ISSAAS Vol. 20, No. 1:93-103, 2014.

[5] Hendroatmojo K. H., "Identification of Constraints and Empowerment Food Ingredients In the preamble Complement Rice", Malang: Balitkabi, 1999.

[6] Md Bellal H., "Effect of Taro Flour Addition on the Functional and Physiochemical Properties of Wheat Flour and Dough for the Processing of Bread", Nutri Food Sci Int J.; vol. 1(2), 2016.

[7] Danimihardja, S. and R. Sujono R., "Variations in Taro (Colocasia esculenta (L.)Schott.)", Annual Rep. of National Biological Institute LIPI, Bogor, 1977.

[8] Jusuf, M., Marzempi and Yohanes. "Status of Taro Genetic Resources in West Sumatera and Research Accomplishment", Unpublished paper, 1996.
[9] Hartati, N. S., Prana, T. K., and Prana, M. S. "Screening Diversity of Taro (C.esculenta (L.) Schott.) Through isozyme analysis". Pros. Biodiversity and Application of Agricultural Biotechnology. Jakarta.

[10] Orji, K., and Ogbonna, "Morphological Correlation Analysis on Some Agronomic Traits of Taro (Colocasia esculenta) in The Plains of Nsukka, Nigeria," Journal of Global Biosciences, vol. 4, no. 1, pp. 1120-1126, 2015.

[11] Trimanto, Sajidan, and Sugiyarto, "Characterization of Taro (Colocasia esculenta) Based on Morphological and Isozymic Patterns Markers”, Bioscience. J., Vol. 2, No. 1, pp. 7-14, 2010

[12] Swasti, E., "Introduction to Plant Breeding", Padang: Department of Agriculture, Faculty of Agriculture, University of Andalas, 2007, p. 144.

[13] J. F. Rohl, "NTSYSpc Numerical Taxonomy and Multivariate Analysis System" version 2.1, Stony Brook, NY 11794-5245: Department of Ecology and Evolution State University of New York, 2000.

[14] K. B. Vinutha, D. A. Asha and S. J, "Morphological Characterization of above Ground Characters of Taro (Colocasia esculenta (L.) Schott.) Accessions from North East India," Journal of Root Crops, vol. 41, no. 1, pp. 3-11, 2015.

[15] S. Kusumo, M. H., M, S. T, Machmud, H. Subadriyo, N. Atmadja, K. Agus and Husni, "Free Characterization and Evaluation of Germplasm Talas, Department of Agriculture Agricultural Research and Development Agency, National Commission Germplasm, Bogor, 2002 .

[16] Sharma, O.P., Plant Taxonomy. Tata McGraw-Hill Publishing Company Limited, New Delhi, 482 p, 1993.

[17] Kam Nio Oey. Daftar Analisis Bahan Makanan. Fakultas Kedokteran Universitas Indonesia, 1992.

[18] Swasti, E, and Sarwendi, "Starch Producing Plant Management, Appropriate Technology Small Agroindustri West Sumatra", Office Menegristek Permasyarakat for Development and Science and Technology, pp121- 137, 2001.

[19] Davis, P.H, and Heywod, "Principles of Angiosperm Taxonomy", New York, Robert, E. Kreiger Publisher Company. pp 39-42, 1973.

[20] J. M. Sitompul and G. B, "Analysis of Plant Growth", Yogyakarta: Gadjah Mada University Press, pp. 67-78, 1995.

[21] Nurmala, F., Ricson, P. H., Widhayastini, I. M., Widyastuti, U.,Suharsono, "Somaclonal variation induction of Bogor taro (Colocasia esculenta) by gamma irradiation", Biodiversitas, Volume 18, Number 1, Pages: 28-33, 2017. 